\title{
Cytotype VARIATION AND CLONAL DIVERSITY IN POLYPLOID APOMICTIC POPULATIONS OF PILOSELla (COMPOSITEAE, Cichorieae) introduced to southern Patagonia
}

\author{
VARIACIÓN CITOTÍPICA Y DIVERSIDAD CLONAL EN POBLACIONES POLIPLOIDES \\ y APomícticas de PIlosella (Compositae, Cichorieae) introducidas en \\ EL SUR DE LA PATAGONIA
}

\author{
Anna Krahulcová (iD and František Krahulec* (D)
}

Institute of Botany of the Czech Academy of Sciences, CZ-25243 Průhonice, Czech Republic

*frantisek.krahulec@ibot.cas.cz

Citar este artículo KRAHULCOVÁ, A. \& F. KRAHULEC. 2021. Cytotype variation and clonal diversity in polyploid apomictic populations of Pilosella (Compositeae, Cichorieae) introduced to southern Patagonia. Bol. Soc. Argent. Bot. 56: 307-326.

DOI: https://doi. org/10.31055/1851.2372.v56. n3.32767

Recibido: 19 Abr 2021

Aceptado: 18 Ago 2021

Publicado impreso: 30 Set 2021

Editora: Viviana Solis Neffa (iD)

ISSN versión impresa 0373-580X ISSN versión on-line 1851-2372

\section{SUMmary}

Introduction and objectives: The genus Pilosella is native to Europe and Asia, but its species are successful invaders on most continents. These species form an agamic complex with common apomixis. Apomictic species hybridize and have different degree of residual sexuality. Main aim of this paper was to determine if interspecific hybridization already occurred in Patagonia.

M\&M: We analysed seed progeny collected at thirteen populations of Pilosella in southern Argentina and Chile. The taxonomic identity of plants, DNA ploidy level (using flow cytometry), chromosome number, reproduction, formation of parthenogenetic seeds and clonal identity (using isozyme phenotypes) were examined.

Results: No mixed-species population was recorded. Two apomictic clones of $P$. officinarum (one pentaploid and the other hexaploid) were found in populations: eight were hexaploid and one was mixed in cytotype composition. A new species for Patagonia, the apomictic pentaploid $P$. caespitosa, was represented by plants from two Argentinean populations. Some of the progeny plants, cultivated from seeds sampled at three localities, represented seed-fertile aneuploids the morphology of which suggest a hybrid origin with $P$. officinarum as one of the parental species.

Conclusions: The presence of seed-fertile, aneuploid and parthenogenetic hybrids among the cultivated plants signifies an increased risk of the formation of new hybridogeneous genotypes of Pilosella in southern Patagonia.

\section{KEY WORDS}

Alien plants, aneuploidy, clonal diversity, cytotypes, facultative apomixis, hybridization, Patagonia, Pilosella, plant invasion, polyploidy, South America.

\section{RESUMEN}

Introducción y objetivos: El género Pilosella es nativo de Europa y Asia, pero sus especies son invasoras exitosas en la mayoría de continentes. Estas especies forman un complejo agámico en el que la apomixis es común. Las especies apomícticas hibridan y presentan diferentes grados de sexualidad residual. El objetivo de este trabajo fue determinar la existencia de hibridación interespecífica en poblaciones del sur de la Patagonia.

M\&M: Se analizó la descendencia de semillas de Pilosella recolectadas en trece poblaciones del Sur de Argentina y Chile. Se determinó la identidad taxonómica de las plantas, el nivel de ploidía (empleando citometría de flujo), el número cromosómico, el tipo de reproducción, la formación de semillas partenogenéticas y su identidad clonal (caracterizando fenotipos isoenzimáticos).

Resultados: No se registró ninguna población mixta entre especies. Se encontraron dos clones apomícticos de $P$. officinarum (uno pentaploide y otro hexaploide) en varias poblaciones: ocho de ellas fueron hexaploides; mientras que una presentó ambos citotipos. La presencia de la especie apomíctica y pentaploide $P$. caespitosa en dos poblaciones de Argentina supone el primer registro de esta especie en la Patagonia. Algunas semillas muestreadas en tres localidades mostraron una descendencia aneuploide fértil, cuya morfología indicó un origen híbrido con $P$. officinarum como una de las especies parentales.

Conclusiones: La presencia de híbridos partenogenéticos, aneuploides y con semillas fértiles entre las plantas cultivadas, implica un aumento del riesgo de formación de nuevos genotipos híbridos de Pilosella en el sur de la Patagonia.

\section{Palabras clave}

América del Sur, aneuploidía, apomixis facultativa, citotipos, diversidad clonal, hibridación, invasión de plantas, Patagonia, Pilosella, plantas invasoras, poliploidía. 


\section{INTRODUCTION}

The agamic complex Pilosella Hill., formerly placed in the genus Hieracium L. in its broad sense, includes strictly sexual diploids and polyploids (up to the octoploid level, the basic chromosome number $x=9$ ) that are predominantly facultatively apomictic and less commonly sexual (Krahulcová et al., 2000). All Pilosella species are native to Eurasia and most of them occur in Europe (Fehrer et al., 2007). Multiple species or cytotypes often coexist within a population, and interspecific and intercytotype hybridization is rather common (Fehrer et al., 2007; Krahulcová et al., 2009, 2014). The still commonly used taxonomic concept is primarily based on morphological characters, distinguishing between 'basic' species and 'intermediate' species (Zahn, 1922-1930; Bräutigam, 2017). Basic species possess unique morphological characters whereas intermediate species combine morphological characters of two or more basic species (Zahn, 1922-1930; Fehrer et al., 2007; Bräutigam, 2017). Supposed hybrid origins of intermediate species have in many cases been inferred from early crossing experiments (Peter, 1884; Nägeli \& Peter, 1885). The morphological characters of intermediate species are expressed using hybrid formulas that reflect either a balanced contribution of both parents (sign '-') or a prevalence/less distinct influence of either parent (signs '>' or '<'; Zahn, 1922-1930; Bräutigam, 2017).

Preferring unproductive habitats, Pilosella species are capable colonizers of disturbed habitats (Fehrer et al., 2007). Several polyploid species have become a weed problem in the secondary distribution area of the genus (e.g. Makepeace, 1985; Jenkins \& Jong, 1996; Wilson et al., 2006; Loomis \& Fishman, 2009; Cipriotti et al., 2010). Their success as invaders in North and South America, New Zealand and Northeastern Asia is mainly enabled by their reproductive versatility (for an overview of the secondary distribution area, see Fehrer et al., 2007). Whereas facultatively apomictic reproduction, together with clonal growth, facilitates the establishment and rapid spread of new populations, residual sexuality maintains a potential for hybridization allowing the generation of new genotypes (Fehrer et al., 2007; Krahulcová et al., 2014). To date, five Pilosella species have been reported from Patagonia: $P$. officinarum F. W. Schultz et Sch. Bip. (under the name of Hieracium pilosella L., first published by Moore, 1983 and many authors later), P. aurantiaca (L.) F. W. Schultz et Sch. Bip. (H. aurantiacum L.: Zuloaga \& Morrone, 1999; Ugarte et al., 2011; Ariza Espinar \& Cerana, 2015; Rodriguez et al., 2018), P. praealta (Gochnat) F. W. Schultz et Sch. Bip. (H. praealtum Gochnat: Zuloaga \& Morrone, 1999; Ugarte et al., 2011; Ariza Espinar \& Cerana 2015 - the figure indicates P. piloselloides (Vill.) Soják; Rodriguez et al., 2018), P. flagellaris (Willd.) Arv.-Touv. (H. flagellare Willd.: Moore, 1983) and P. floribunda (Wimm. et Grab.) Fr. (H. floribundum Wimm. et Grab.: Krahulec \& Krahulcová, 2011). Surprisingly, P. officinarum F. W. Schultz et Sch. Bip. (H. pilosella) has been reported to not occur in Flora of Argentina (Ariza Espinar \& Cerana, 2015, but it is often reported in ecological papers, e.g. Rauber et al., 2013, Braun et al., 2019).

Both native and alien populations of Pilosella have primarily been studied with respect to ecological traits supporting invasiveness, such as seed germination and adaptation to environmental conditions (Beckmann et al., 2011), dynamics of vegetative and generative reproduction (Makepeace, 1985; Beckmann et al., 2009), and the relationship between environmental and ecological factors influencing population dynamics and spread (Cipriotti et al., 2010, 2012; Day \& Buckley, 2011; Rauber et al., 2014; Cook et al., 2021). Follow-up research aimed to devise appropriate management practices to restrict the spread of invasive $P$. officinarum in natural grasslands, for example in New Zealand (e.g. Scott, 1993; Walker et al., 2016) or in Argentinian Patagonia (Cipriotti et al., 2012, 2014). The geographic origin of invasive populations of Pilosella was traced by comparing the DNA molecular markers in natural populations in Europe and in alien populations in New Zealand (Trewick et al., 2004) and in North America (Wilson et al., 2006; Loomis \& Fishman, 2009). Evidence of recent interspecific/intraspecific hybridization in facultatively apomictic alien populations of Pilosella in New Zealand is based on chloroplast DNA markers (Trewick et al., 2004), inter-simple sequence repeats and allozyme markers (Chapman et al., 2003), as well as species-specific parental genome sizes reflected in hybrids (Morgan-Richards et al., 2004; Suda et al., 2007).

The reproductive system largely determines the ease of progeny formation and progeny diversity. 


\section{A. Krahulcová and F. Krahulec - Pilosella in Patagonia}

These aspects are important for invasion success, but they have until recently been overlooked in alien populations of Pilosella in Patagonia. Our previous study, focused on karyological, reproductive and clonal diversity in the seed progeny of $P$. officinarum originating from three localities in Chilean Patagonia, was the first to take account of reproductive traits of Pilosella in South America (Krahulec \& Krahulcová, 2011). The cultivated plants belonged to two clones of $P$. officinarum, one pentaploid and the other hexaploid. Both clones exhibited a high degree of apomictic reproduction facilitating easy seed formation independent of a compatible pollinating parent (Krahulec \& Krahulcová, 2011). Later on, in 2013, our colleagues took samples of seeds in populations of Pilosella at an additional thirteen localities in southern Argentina and Chile (Table 1). The study presented here is based on the evaluation of individual mature plants raised from these seeds, especially with respect to their (a) taxonomic identity, (b) DNA ploidy level/ chromosome number, (c) reproductive behaviour (i.e. the potential for parthenogenetic seed formation), and (d) clonal identity illustrating genotype diversity. If the cultivated progeny proved to be heterogeneous in either morphological/karyological characters or in clonal structure, the remaining available seeds were used for the determination of seed origin. The methodical approach followed the one used previously for analysing seeds of Pilosella from the field and cultivated progeny plants (e.g. Krahulec \& Krahulcová 2011; 2018).

Because of the known occurrence of at least five morphologically distinct species of Pilosella in Patagonia (Moore, 1983; Zuloaga \& Morrone, 1999; Cipriotti et al., 2010; Krahulec \& Krahulcová, 2011, Ariza Espinar \& Cerana, 2015), we tried to ascertain whether each of the thirteen populations sampled is composed of a single species or whether at least some of them were composed of more than one species. Among the progeny grown from seeds we especially looked for traits that may be indicative of sexual reproduction potentially taking place in the field. Such traits are, for example, specific combinations of certain parental morphological characters reflecting interspecific hybridization, aneuploidy and intraspecific clonal diversity within populations. Better knowledge of reproductive traits and population structure may help to understand the possibly advancing invasion of Pilosella in Patagonia.

\section{Material ANd Methods}

\section{Seed sampling and recovery of progeny plants}

In the late summer of 2013, Petra Šarhanová (Leibnitz-Institut für Pflanzengenetik und Kulturpflanzenforschung, Gatersleben, Germany) and Erwin Domínguez (INIA Kampenaike, Punta Arenas, Chile) collected, independently of each other, seeds in thirteen populations of Pilosella in Chilean Patagonia (both collectors) and Argentinian Patagonia (exclusively P. Šarhanová; Table 1). The two collectors used different seed-sampling strategies. Because of the limited time spent at each locality, Petra Šarhanová sampled seeds together from all available fruiting Pilosella plants at each locality. This sampling strategy is likely to have increased the heterogeneity of these seed samples (accessions 2102-2111 in Table 1 and Table 2). The reason for this simplified seed sampling was that was carried out during an expedition to Patagonia conducted as part of a different project. Erwin Domínguez sampled separately the fruiting inflorescences (capitula) of individual maternal plants of $P$. officinarum (accessions 2113-2117 in Table 1 and Table 2). A map of all collection sites is provided in Fig. 1. The maximum distance between localities in the northwest to southeast direction was ca $500 \mathrm{~km}$ and the maximum distance in the southwest to northeast direction was ca $170 \mathrm{~km}$ (Fig. 1). All the collection sites were situated in the close vicinity of roads. Herbarium specimens of fruiting maternal plants were not collected.

The material used is based on progeny plants that were grown from seeds, alternatively on remaining seeds that were not used for cultivation of the progeny. Examining the cultivated progeny plants, the following methodological approach was used: 1) assessment of morphological appearance that resulted to determination of particular species (Bräutigam \& Greuter, 2007-2009; Bräutigam, 2017); 2) search for apomictic reproduction, i.e., for an ability to produce the seed progeny that replicates the maternal parent (both the cultivated progeny plants and remaining seeds were used for this purpose); 3) determination of ploidy level/chromosome number reflecting the cytotypic diversity; 4) search for the clonal diversity within particular species/morphotypes and cytotypes using the isoenzyme analysis; 5) evaluation of the pollen quality (reflected in pollen stainability) in two selected representatives of an euploid basic species 
Table 1. Collection data of Pilosella plants from southern Patagonia. Plants were grown from seeds sampled in the field by Petra Šarhanová (PŠ) and Erwin Domínguez (ED). Taxonomic determination of cultivated plants was done by S. Bräutigam and F. Krahulec.

\begin{tabular}{|c|c|c|c|c|c|c|c|}
\hline $\begin{array}{l}\text { Locality } \\
\text { No. }\end{array}$ & $\begin{array}{c}\text { Accession } \\
\text { label }\end{array}$ & Species & Country, location & Habitat & Coordinates & $\begin{array}{c}\text { Elevation } \\
(\mathrm{msnm})\end{array}$ & $\begin{array}{l}\text { Collector } \\
\text { of } \\
\text { seeds, } \\
\text { date }\end{array}$ \\
\hline 1. & 2102 & P. caespitosa & $\begin{array}{l}\text { Argentina, Santa } \\
\text { Cruz, S of Estancia } \\
\text { Cancha Carrera, } 30 \\
\text { km N of Rio Turbio }\end{array}$ & $\begin{array}{l}\text { in open, patchy } \\
\text { Nothofagus forest } \\
\text { in upper Rio } \\
\text { Turbio valley }\end{array}$ & $\begin{array}{l}51^{\circ} 24^{\prime} 41^{\prime \prime S}, \\
72^{\circ} 13^{\prime} 42^{\prime \prime} \mathrm{W}\end{array}$ & 428 & $\begin{array}{l}\text { PŠ, } 2 \\
\text { Feb } \\
2013\end{array}$ \\
\hline 2. & 2103 & P. officinarum & $\begin{array}{l}\text { Chile, Region XII, } \\
\text { Tierra del Fuego, } \\
\text { W of Manantiales }\end{array}$ & $\begin{array}{l}\text { overgrazed steppe } \\
\text { with all plants small } \\
\text { (no bushes), lot of } \\
\text { Empetrum cushions }\end{array}$ & $\begin{array}{l}52^{\circ} 31^{\prime} 17^{\prime \prime} \mathrm{S}, \\
69^{\circ} 29^{\prime} 40^{\prime \prime} \mathrm{W}\end{array}$ & 15 & $\begin{array}{l}\text { PŠ, } 4 \\
\text { Feb } \\
2013\end{array}$ \\
\hline 3. & 2104 & P. officinarum & $\begin{array}{l}\text { Chile, Region XII, } \\
\text { Tierra del Fuego, } \\
\text { W of Manantiales }\end{array}$ & $\begin{array}{l}\text { grass dominated } \\
\text { steppe }\end{array}$ & $\begin{array}{l}52^{\circ} 43^{\prime} 60^{\prime \prime} \mathrm{S} \\
69^{\circ} 03^{\prime} 33^{\prime \prime} \mathrm{W}\end{array}$ & 67 & $\begin{array}{l}\text { PŠ, } 4 \\
\text { Feb } \\
2013\end{array}$ \\
\hline 4. & 2105 & P. officinarum & $\begin{array}{l}\text { Chile, Region XII, } \\
\text { Tierra del Fuego, } \\
\text { W of Manantiales }\end{array}$ & $\begin{array}{l}\text { grass dominated } \\
\text { steppe }\end{array}$ & $\begin{array}{l}52^{\circ} 32^{\prime} 05^{\prime \prime} \mathrm{S} \\
69^{\circ} 23^{\prime} 51^{\prime \prime} \mathrm{W}\end{array}$ & 5 & $\begin{array}{l}\text { PŠ, } 7 \\
\text { Feb } \\
2013\end{array}$ \\
\hline 5. & 2106 & $\begin{array}{l}\text { P. brachiata / } \\
\text { P. piloselliflora }\end{array}$ & $\begin{array}{l}\text { Argentina, Tierra } \\
\text { del Fuego, } \mathrm{N} \text { of } \\
\text { Tolhuin along R3 }\end{array}$ & $\begin{array}{l}\text { bog vegetation with } \\
\text { Berberis empetrifolia } \\
\text { within Nothofagus } \\
\text { forest area }\end{array}$ & $\begin{array}{l}54^{\circ} 27^{\prime} 45^{\prime \prime} \mathrm{S}, \\
67^{\circ} 12^{\prime} 22^{\prime \prime} \mathrm{W}\end{array}$ & 99 & $\begin{array}{l}\text { PŠ, } 5 \\
\text { Feb } \\
2013\end{array}$ \\
\hline 6. & 2108 & $\begin{array}{l}\text { P. brachiata / } \\
\text { P. piloselliflora }\end{array}$ & $\begin{array}{l}\text { Argentina, Tierra del } \\
\text { Fuego, at coast of } \\
\text { Beagle Channel, } 10 \\
\text { km W of Estancia } \\
\text { Harberton }\end{array}$ & $\begin{array}{l}\text { meadow on top } \\
\text { of the hill }\end{array}$ & $\begin{array}{l}54^{\circ} 49^{\prime} 28^{\prime \prime} \mathrm{S}, \\
67^{\circ} 30^{\prime} 03^{\prime \prime} \mathrm{W}\end{array}$ & 110 & $\begin{array}{l}\text { PŠ, } 6 \\
\text { Feb } \\
2013\end{array}$ \\
\hline 7. & 2109 & P. officinarum & $\begin{array}{l}\text { Chile, Region XII, } \\
\text { Tierra del Fuego, } \\
\text { coast E of Pt. } \\
\text { Nuevo along Y71 }\end{array}$ & not specified & $\begin{array}{l}53^{\circ} 21^{\prime} 15^{\prime \prime S}, \\
69^{\circ} 22^{\prime} 11^{\prime \prime} \mathrm{W}\end{array}$ & 11 & $\begin{array}{l}\text { PŠ, } 7 \\
\text { Feb } \\
2013\end{array}$ \\
\hline 8. & 2110 & P. officinarum & $\begin{array}{l}\text { Chile, Region XII, } \\
\text { Tierra del Fuego, } \\
\text { along R257 S of } \\
\text { Cerro Sombrero }\end{array}$ & $\begin{array}{l}\text { grass dominated } \\
\text { steppe }\end{array}$ & $\begin{array}{l}53^{\circ} 11^{\prime} 23^{\prime \prime} \mathrm{S}, \\
69^{\circ} 16^{\prime} 35^{\prime \prime} \mathrm{W}\end{array}$ & 73 & $\begin{array}{l}\text { PŠ, } 7 \\
\text { Feb } \\
2013\end{array}$ \\
\hline 9. & 2111 & P. caespitosa & $\begin{array}{l}\text { Argentina, Santa } \\
\text { Cruz, Laguna Azul }\end{array}$ & $\begin{array}{l}\text { lava rocks and } \\
\text { outcrops }\end{array}$ & $\begin{array}{l}52^{\circ} 04^{\prime} 30^{\prime \prime} \mathrm{S}, \\
69^{\circ} 34^{\prime} 53^{\prime \prime} \mathrm{W}\end{array}$ & 131 & $\begin{array}{l}\text { PŠ, } 7 \\
\text { Feb } \\
2013\end{array}$ \\
\hline 10. & $\begin{array}{l}2113+ \\
2114\end{array}$ & P. officinarum & $\begin{array}{l}\text { Chile, XII Reg., } \\
\text { Prov. Mag., Sector } \\
\text { Barranco Amarillo, } \\
\text { Com. Punta Arenas }\end{array}$ & not specified & $\begin{array}{l}53^{\circ} 05^{\prime} 00^{\prime \prime}- \\
53^{\circ} 05^{\prime} 01^{\prime \prime} \mathrm{S}, \\
70^{\circ} 52^{\prime} 25^{\prime \prime}- \\
70^{\circ} 52^{\prime} 26^{\prime \prime} \mathrm{W}\end{array}$ & $44-45$ & $\begin{array}{l}\text { ED, } \\
5 \text { Jan } \\
2013 \\
\text { and } 23 \\
\text { Feb } \\
2013\end{array}$ \\
\hline 11. & 2115 & P. officinarum & $\begin{array}{l}\text { Chile, XII Reg., } \\
\text { Prov. Mag., Sector } \\
\text { 805, Punta Arenas, } \\
\text { Ruta No } 9\end{array}$ & not specified & $\begin{array}{l}53^{\circ} 17^{\prime} 31 \text { 'S } \\
70^{\circ} 56^{\prime} 12^{\prime \prime} \mathrm{W}\end{array}$ & 0 & $\begin{array}{l}\text { ED, } \\
18 \text { Jan } \\
2013\end{array}$ \\
\hline 12. & 2116 & P. officinarum & $\begin{array}{l}\text { Chile, XII Reg., } \\
\text { Prov. Mag., Sector } \\
\text { Los Cineces }\end{array}$ & not specified & $\begin{array}{l}53^{\circ} 20^{\prime} 13^{\prime \prime} \mathrm{S} \\
70^{\circ} 57^{\prime} 03^{\prime \prime} \mathrm{W}\end{array}$ & 0 & $\begin{array}{l}\text { ED, } \\
18 \text { Jan } \\
2013\end{array}$ \\
\hline 13. & 2117 & P. officinarum & $\begin{array}{l}\text { Chile, XII Reg., } \\
\text { Prov. Mag., Sector } \\
\text { Agua Fresca }\end{array}$ & not specified & $\begin{array}{l}53^{\circ} 23^{\prime} 39^{\prime \prime} \mathrm{S} \\
70^{\circ} 59^{\prime} 25^{\prime \prime} \mathrm{W}\end{array}$ & 0 & $\begin{array}{l}\text { ED, } \\
18 \text { Jan } \\
2013\end{array}$ \\
\hline
\end{tabular}




\section{A. Krahulcová and F. Krahulec - Pilosella in Patagonia}

Table 2. Cytotype, reproductive and clonal-identity attributes of Pilosella plants that were grown from seeds sampled in the field in southern Patagonia.

\begin{tabular}{|c|c|c|c|c|c|c|c|}
\hline $\begin{array}{c}\text { Accession } \\
\text { label }\end{array}$ & Species & $\begin{array}{l}\text { Sampling } \\
\text { design }\end{array}$ & $\begin{array}{l}\text { Nr of } \\
\text { plants } \\
\text { grown }\end{array}$ & $\begin{array}{l}\text { DNA } \\
\text { ploidy } \\
\text { level }\end{array}$ & $\begin{array}{c}\text { Chromosome } \\
\text { number }(2 n)\end{array}$ & $\begin{array}{l}\text { Production of } \\
\text { parthenogenetic } \\
\text { seeds }\end{array}$ & $\begin{array}{l}\text { Isozyme } \\
\text { phenotype }\end{array}$ \\
\hline 2102 & P. caespitosa & $\mathrm{CP}$ & 20 & $5 x(20)$ & $45 \mathrm{M}(1)$ & yes (3) & b (3) \\
\hline 2103 & $P$. officinarum & $\mathrm{CP}$ & 22 & $6 x(22)$ & n.d. & yes (4) & a (2) \\
\hline \multirow[b]{2}{*}{2104} & P. officinarum & \multirow[b]{2}{*}{$\mathrm{CP}$} & \multirow[b]{2}{*}{21} & $6 x(20)$ & $54(1)$ & yes (2) & a (2) \\
\hline & $\begin{array}{l}P . \text { officinarum } \times \\
\text { unknown parent }\end{array}$ & & & $<6 x(1)$ & $51(1)$ & n.d. & a (1) \\
\hline 2105 & $P$. officinarum & $\mathrm{CP}$ & 20 & $6 x(20)$ & $54(1)$ & yes(2) & a (2) \\
\hline 2106 & $\begin{array}{l}\text { P. brachiata / } \\
\text { P. piloselliflora }\end{array}$ & $\mathrm{CP}$ & 18 & $5 x(18)$ & $46(4)$ & yes (2) & $c(5), d(12), h(1)$ \\
\hline \multirow{2}{*}{2108} & P. brachiata / & \multirow{2}{*}{$\mathrm{CP}$} & \multirow{2}{*}{21} & $5 x(20)$ & $44(13)$ & n.d. & $c(2), d(16), e(2)$ \\
\hline & P. piloselliflora & & & $<5 x(1)$ & $39(1)$ & n.d. & $f(1)$ \\
\hline 2109 & P. officinarum & $\mathrm{CP}$ & 9 & $6 x(9)$ & $54(1)$ & yes (3) & a (2) \\
\hline 2110 & P. officinarum & $\mathrm{CP}$ & 22 & $6 x(22)$ & $54(1)$ & yes (2) & $\mathrm{a}(2)$ \\
\hline 2111 & P. caespitosa & $\mathrm{CP}$ & 16 & $5 x(16)$ & $45 \mathrm{M}(2)$ & yes (3) & b (3) \\
\hline 2113 & \multirow{2}{*}{$P$. officinarum } & IFC (6) & 14 & $5 x(14)$ & $45(1)$ & n.d. & $g(7)$ \\
\hline 2114 & & IFC (10) & 28 & $6 x(28)$ & n.d. & n.d. & a (3) \\
\hline 2115 & $P$. officinarum & IFC (10) & 30 & $6 x(30)$ & n.d. & n.d. & a (1) \\
\hline 2116 & P. officinarum & IFC (10) & 30 & $6 x(30)$ & $54(1)$ & n.d. & a (1) \\
\hline 2117 & $P$. officinarum & IFC (10) & 28 & $6 x(28)$ & n.d. & n.d. & $\mathrm{a}(1)$ \\
\hline
\end{tabular}

References: Accession labels refer to the respective localities listed in Table 1. Design of seed sampling: accessions $2102-2111$ represent the composite progenies (CP) of all seeding maternal plants that were available at locality; accessions $2113-2117$ comprise the progeny arrays sourced from individual fruiting capitula (IFC) sampled separately at each locality. The number of fruiting capitula sampled and the number of analysed plants are given in parentheses. The DNA ploidy level was determined using flow cytometry, the basic chromosome number in Pilosella is $x=9$. The different isozyme phenotypes (clones), designated by specific letters, were distinguished using a combined pattern of four enzyme systems analysed (see $M$ \& $M$ section for details). The isozyme phenotype ' $f$ ' within a multiclonal accession 2108 refers to plant with a somatic chromosome number of $2 n=39$ presented in the same row. Some of the diverse cytotypes that undoubtedly represent different clones, still shared identical isozyme phenotypes: specifically, the phenotype 'a' was shared by two cytotypes within accession 2104 and phenotypes ' $c$ ' and ' $d$ ' were shared by two cytotypes comprising the accessions 2106 and 2108 . The isozyme phenotype 'a' has previously been detected in hexaploid apomictic $P$. officinarum originating from two other localities in Patagonia whereas the isozyme phenotype ' $g$ ' has previously been detected in pentaploid apomicic $P$. officinarum originating from another locality in this region (Krahulec \& Krahulcová, 2011). Abbreviations and symbols used: M - a long hemizygous (marker) chromosome is present in the karyotype; n.d. - not determined.

and of an aneuploid putative hybrid, respectively: this indicative test allowed to estimate if the transfer of the paternal genome to progeny is possible by means of pollen.

Seeds were sown into pots with sterilized garden soil and were left to germinate in a greenhouse in the experimental garden of the Institute of Botany, Průhonice, Czech Republic. Individual seedlings were replanted into seedling trays and the DNA ploidy level of adequately grown young plants was determined (see below). Later on, the plants were repotted and transferred to outdoor garden beds for 


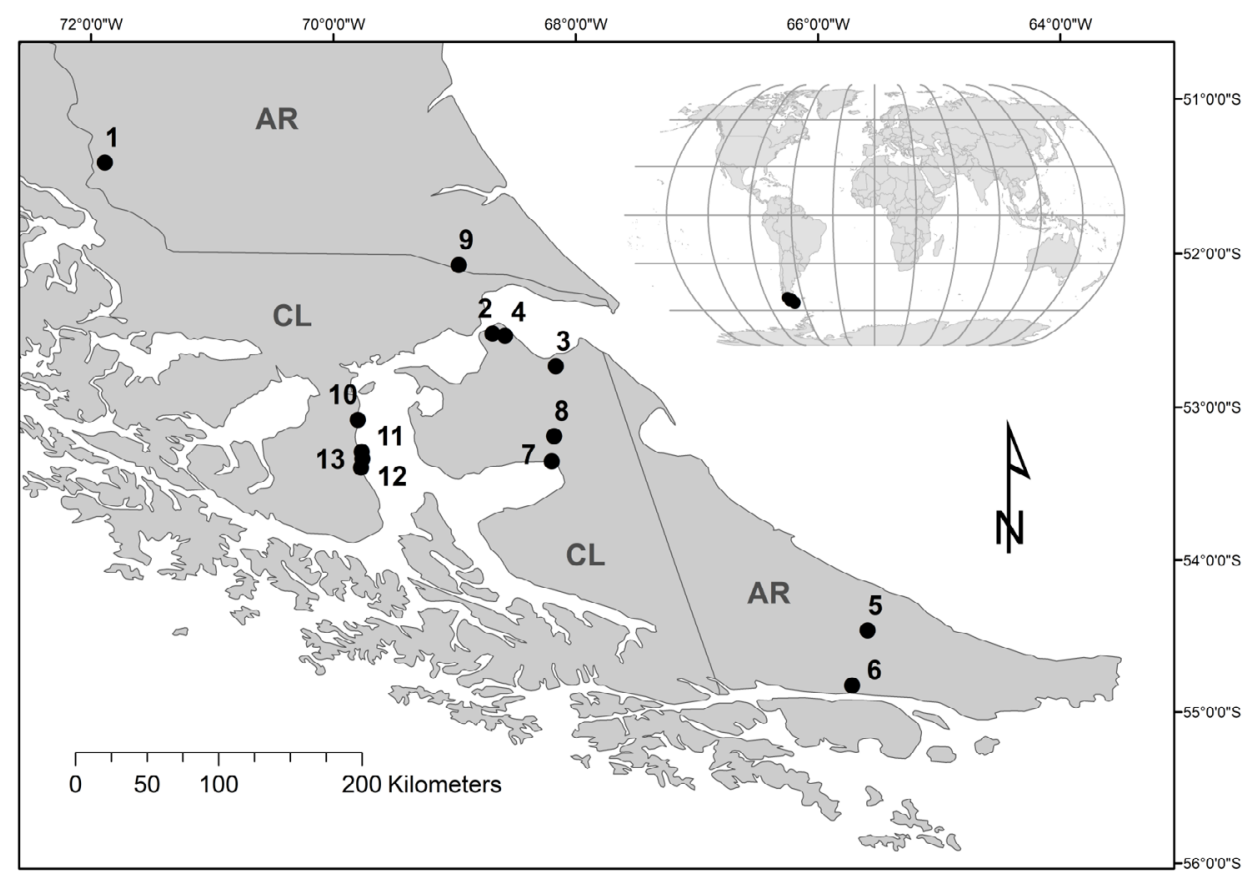

Fig. 1. Map of localities (black circles) in southern Patagonia of Pilosella species under study. The accession labels, corresponding to those presented in Table 1, refer to the following species: $P$. officinarum (accessions 2103, 2104, 2105, 2109, 2110, $2113+2114,2115,2116$ and 2117), P. caespitosa (accessions 2102 and 2111) and P. brachiata/P. piloselliflora (accession 2106 and 2108).

continued cultivation. A total of 299 progeny plants were raised from the seeds (Table 2). Their accession labels correspond to the respective localities where the seeds were sampled (Tables 1 and 2). Accessions 2113 and 2014 share one locality because they were sampled from six and ten nearby occurring maternal plants, respectively (Table 2). Herbarium specimens of cultivated and analysed progeny plants are deposited in the Herbarium of the Institute of Botany, Průhonice (PRA). Determination of species was done by Siegfried Bräutigam (Dresden, Germany) using both live plants grown in the experimental garden and their herbarium specimens. The nomenclature follows Bräutigam \& Greuter (2007-2009) and Bräutigam (2017).

Ploidy level and reproduction mode in recovered progeny

DNA ploidy levels (Suda et al., 2006) were determined in seedlings using flow cytometry
(FCM). The DAPI staining method (Otto, 1990) was applied using the ice-cold nuclei-extracting buffer (Otto I) and the staining buffer (Otto II) supplemented with $2 \mu \mathrm{l} \cdot \mathrm{ml}^{-1}$ mercaptoethanol as an antioxidant. Fluorescence intensity was determined using a CyFlow Ploidy Analyser PA II (Partec $\mathrm{GmbH}$, Münster, Germany) equipped with an HBO high-pressure mercury lamp for UV excitation. For details of the procedure, see Krahulcová et al. (2004). The diploid Pilosella lactucella (Wallr.) P. D. Sell \& C. West (DNA content $4.07 \mathrm{pg} / 2 \mathrm{C}$, Suda et al., 2007) was used as the internal standard. When evaluating the FCM analyses, only histograms in which the coefficient of variance of peaks (hereafter referred to as $\mathrm{CV}$ ) did not exceed 3\% were accepted. A total of 3000 nuclei were scored for each sample.

The reproduction mode was principally determined using the emasculation/open pollination experiment, which allows us to distinguish parthenogenetic (assumed to be apomictic), sexual 


\section{A. Krahulcová and F. Krahulec - Pilosella in Patagonia}

and seed-sterile plants (Gadella, 1984; Krahulcová et al., 2004). Emasculation was carried out by cutting off the whole upper part of an unopened inflorescence (capitulum) before anthesis; the anthers and stigmas were removed, but the ovaries remained untouched. Given that fertilization-independent seed formation is predominantly coupled with apomeiosis in wildtype apomicts within Pilosella, this test is an approximation for apomictically reproducing plants (Bicknell \& Koltunow, 2004; Hand et al., 2015).

\section{Clonal structure}

Clonal (genotypic) identity was examined in each accession and plants representing an identical taxon/cytotype were compared among accessions (Table 2). An extent of morphological and karyological uniformity within an accession was preliminarily assessed, based on a general appearance of plant phenotypes (morphotypes) and on their corresponding cytotypes, respectively. If the cultivated plants showed high morphological and karyological uniformity within an accession, one to three individuals per accession were chosen for the determination of clonal identity. Individuals that showed some diversity in morphological features within an accession were included in addition; 69 plants were analysed for clonal structure in total (Table 2). Clonal identity was inferred from unique patterns of isozyme phenotypes (Table 2) derived from a combination of four tested enzymes (AAT, LAP, 6-PGDH/PGM and EST). Electrophoresis was performed on crude protein extracts of leaf material. Tissue was ground in ice-cold Tris- $\mathrm{HCl}$ extraction buffer: $0.1 \mathrm{M}$ Tris$\mathrm{HCl} \mathrm{pH} \mathrm{8.0;} 70 \mathrm{mM}$ 2-mercaptoethanol, $26 \mathrm{mM}$ sodium metabisulfite, $11 \mathrm{mM}$ ascorbic acid, $4 \%$ polyvinyl-pyrrolidone. Roughly $60 \mathrm{mg}$ of fresh leaf material was homogenized with Dowex.Cl (1-X8) on ice in $0.7 \mathrm{ml}$ of extraction buffer. Extracts were centrifuged for $10 \mathrm{~min}$ at $13,000 \mathrm{rpm}$ and clear supernatants were stored at $-75^{\circ} \mathrm{C}$. All enzyme systems were investigated on polyacrylamide gels (8\% acrylamide, discontinuous tris-glycine buffer system, $\mathrm{pH}$ 8.3). The staining procedures followed Vallejos (1983) -LAP (Fast Black K), AAT (+ Fast Violet B) and Wendel \& Weeden (1989) -6-PGDH, PGM (NADP), EST-colorometric (b-naphtyl phosphate, Fast Blue BB) with modifications. The isoenzyme patterns were visually compared among individual plants. In previous studies, enzymatic systems provided sufficient resolution within individual cytotypes of numerous polyploid taxa of Pilosella (Krahulec et al., 2004; Krahulcová et al., 2009, 2014; Krahulcová \& Krahulec, 2020).

\section{Chromosome numbers and pollen stainability}

Chromosome numbers were determined especially for selected plants which represented individual accessions and individual clones as implied from specific isozyme phenotypes. In those sporadic aberrant plants that were distinguishable by morphological traits from other plants within each of the two accessions 2104 and 2108, the chromosomes were counted as well (Table 2). Plants that were uniform in morphology and belonged to a common hexaploid clone of $P$. officinarum (i.e. bearing the isozyme phenotype labelled ' $a$ ' in Table 2) were cytotyped in only five out of the ten accessions in which this clone was recorded (Table 2). Chromosomes were counted in metaphases in root-tip meristems. Root-tips were pre-treated with a saturated solution of $\alpha$-bromonaphtalene for 3 hours at room temperature, rinsed in water and fixed in cold acetic-ethanol (1:3) overnight. The fixed material was stored in $70 \%$ ethanol at 4 ${ }^{\circ} \mathrm{C}$ until required. The maceration was carried out in $1 \mathrm{~N} \mathrm{HCl}$ at $60{ }^{\circ} \mathrm{C}$ for $7 \mathrm{~min}$. The root-tips were then rinsed in water and the cut meristems were squashed in a drop of lacto-propionic orcein (Dyer, 1963). Only temporary slides were made.

An indicative evaluation of pollen fertility was carried out for one plant representing the common eu-hexaploid $P$. officinarum $(2 n=54)$ and for one aneuploid plant $(2 n=46)$ of a putative hybrid origin, representing the morphotype of the hybridogeneous species $P$. brachiatal $P$. piloselliflora (for explanation see Discussion, Apomictic nature...). Pollen fertility was estimated as pollen stainability using Alexander's stain (Alexander, 1969). The stain was applied to fresh pollen, following the procedure described by Rotreklová \& Krahulcová (2016). A total of 300 pollen grains were evaluated per plant.

\section{Reproductive origins in seeds and embryo ploidy} levels

Reproductive origins and embryo ploidy levels were screened in accessions 2104, 2105 and 2108, using the remaining seeds that were sampled in the field but not used to obtain progeny. Flow 
cytometric seed screening (FCSS) was used (Matzk et al., 2000) with the following modifications for Pilosella: The seeds were kept in a fridge in order to retain endosperm tissue, allowing us to get interpretable endosperm peaks in flow-cytometric histograms for up to several months. Before the analysis, filled (well developed) seeds were screened under a stereomicroscope by putting appropriate pressure with tweezers on each seed. Filled seeds were pooled either two at a time (Table 3 ) or ten at a time (Table 4), so either seed doublets or groups comprising ten seeds each were prepared for FCM analysis. If possible, 5000 nuclei were scored for each sample analysed. Basically, the procedure was the same as the one used for the detection of ploidy level in seedlings (see above).

When analysing seed doublets, two cypselae (achenes) were chopped in the nuclei-isolating buffer with a razor blade together with $0.05 \mathrm{~cm}^{2}$ of leaf tissue of Bellis perennis L. (DNA content $3.96 \mathrm{pg} / 2 \mathrm{C}$, Leong-Škorničková et al., 2007) as the reference standard. The suspension was filtered and incubated for $10 \mathrm{~min}$ at room temperature, stained and analysed (Krahulcová et al., 2009, 2011). Histograms with CVs below 3.5\% were considered. When analysing pooled samples comprising ten seeds, ten cypselae were chopped in the nuclei-isolating buffer with a razor blade, and the suspension was filtered and incubated for $10 \mathrm{~min}$ at room temperature, stained and analysed (Krahulcová \& Suda, 2006; Krahulcová et al., 2011). The maternal ploidy peak was used as the internal ploidy standard and histograms with CVs below 5\% were considered. This threshold of accuracy of analyses was still acceptable because two simultaneous peaks in a histogram are indicative of a difference in DNA content between two components within a sample, corresponding to double the CV (Doležel \& Göhde, 1995). The quantification of embryo ploidy classes was based on the proportions of nuclei in their respective embryo ploidy peaks (Krahulcová \& Suda, 2006).

The FCSS analysis allows us to detect both the ploidy level of progeny embryos (when analysing both the seed doublets and pooled samples of ten seeds) and their reproductive origins (when analysing the seed doublets). FCSS analyses of pooled seed samples sourced from facultatively apomictic mothers commonly reveal the most frequent embryos of apomictic origin that maintain the maternal ploidy level; in addition, this procedure can distinguish and quantify the number of potential less frequent embryos differing in ploidy level from the maternal parent, namely, the products of (a) heteroploid crosses, (b) sexual mating via unreduced gametes and (c) haploid parthenogenesis (Krahulcová \& Suda, 2006). This way, the potential diversity in embryo ploidy level can be traced.

Table 3. Flow cytometric seed screening (FCSS) of remaining seeds (seed doublets) of Pilosella from the field that were not used to obtain progeny. The accession symbols and chromosome numbers that were detected paralelly among cultivated plants, follow Table 2 . The basic chromosome number in Pilosella is $x=9$. Symbols of species: OFF $-P$. officinarum; BRA - P. brachiata; PF $-P$. piloselliflora. The symbol of seed origin $2 n+0$ (Harlan and de Wet 1975) refers to apomictic origin of embryo. For description of both FCSS methods used and for their detection capacity, see M \& M section.

\begin{tabular}{|c|c|c|c|c|c|c|c|}
\hline \multirow{3}{*}{ Accession } & \multirow[t]{3}{*}{$\begin{array}{l}\text { grown frc } \\
\text { source of }\end{array}$} & \multirow{3}{*}{$\begin{array}{l}\text { Chromosome } \\
\text { number }\end{array}$} & \multicolumn{5}{|c|}{$\begin{array}{l}\text { FCSS analysis of seed doublets } \\
\text { Seed origin }\end{array}$} \\
\hline & & & \multicolumn{2}{|c|}{$2 n+0$} & \multicolumn{2}{|c|}{ Other } & \multirow[t]{2}{*}{ Total Nr of seeds } \\
\hline & & & $\begin{array}{l}\text { Embryo } \\
\text { ploidy }\end{array}$ & $\begin{array}{l}\text { Nr of } \\
\text { seeds }\end{array}$ & $\begin{array}{l}\text { Embryo } \\
\text { ploidy }\end{array}$ & $\begin{array}{l}\text { Nr of } \\
\text { seeds }\end{array}$ & \\
\hline 2104 & OFF & $\begin{array}{c}2 n=6 x=54 \\
2 n=51\end{array}$ & $6 x$ & 20 & - & 0 & 20 \\
\hline 2105 & OFF & $2 n=6 x=54$ & $6 x$ & 20 & - & 0 & 20 \\
\hline \multirow[t]{2}{*}{2108} & BRA/PF & $\begin{array}{c}2 n=\text { ca } 5 x= \\
44,2 n=39\end{array}$ & ca $5 x$ & 12 & - & 0 & 12 \\
\hline & & & & & & & 52 \\
\hline
\end{tabular}




\section{A. Krahulcová and F. Krahulec - Pilosella in Patagonia}

Table 4. Flow cytometric seed screening (FCSS) of remaining seeds (bulked samples of ten seeds) of Pilosella from the field that were not used to obtain progeny. For explanation see Table $3 .{ }^{a}$ The embryo ploidy level corresponds to polyhaploid origin $(n+0$, Fig. 3C).

\begin{tabular}{|c|c|c|c|c|c|c|c|}
\hline \multirow[b]{2}{*}{ Accession } & \multirow[b]{2}{*}{ Species } & \multirow[b]{2}{*}{$\begin{array}{c}\text { Chromosome } \\
\text { number }\end{array}$} & \multicolumn{5}{|c|}{ FCSS analysis of bulked samples comprising 10 seeds } \\
\hline & & & $\begin{array}{c}\text { Maternal } \\
\text { embryo ploidy }\end{array}$ & Nr of seeds & $\begin{array}{l}\text { Other embryo } \\
\text { ploidy }\end{array}$ & $\mathrm{Nr}$ of seeds & $\begin{array}{l}\text { Total Nr } \\
\text { of seeds }\end{array}$ \\
\hline 2104 & OFF & $\begin{array}{c}2 n=6 \mathrm{x}= \\
54,2 n=51\end{array}$ & $6 x$ & 47 & $3 x^{a}$ & 3 & 50 \\
\hline 2108 & BRA/PF & $\begin{array}{c}2 n=\text { ca } 5 x= \\
44,2 n=39\end{array}$ & ca $5 x$ & 50 & - & 0 & 50 \\
\hline & & & & & & & 100 \\
\hline
\end{tabular}

\section{Results}

Taxonomic identity, cytotypes and pollen stainability

The plants cultivated from seeds originating from nine populations in Chile represented the basic species Pilosella officinarum (Table 1, Table 2, Fig. 1). Hexaploids $(2 n=54)$ prevailed whereas pentaploids $(2 n=45)$ were detected only among plants of $P$. officinarum which made up a mixed pentaploid/hexaploid population situated close to Punta Arenas (accessions 2113 and 2114 in Table 2, Fig. 1). While both hexaploids and pentaploids morphologically matched typical $P$. officinarum, the rather deviating appearance of a single plant within hexaploid accession 2104 suggested that this plant is a hybrid of $P$. officinarum and another, unknown species (Table 2). This atypical plant turned out to be aneuploid $(2 n=51$, Fig. $2 \mathrm{~A})$ lacking the three chromosomes when compared with the euhexaploid cytotype $(2 n=54)$.

Another basic species that was recorded among the progeny plants was Pilosella caespitosa (Dumort.) P.D. Sell \& C. West from two localities in Argentina (accessions 2102 and 2111 in Table 1 and Table 2). All 36 raised plants of $P$. caespitosa were pentaploid (Table 2). Chromosome counting of three selected plants of $P$. caespitosa revealed the chromosome number of $2 n=45$, which included a long hemizygous chromosome (symbol ' $\mathrm{M}$ ' following the chromosome number in Table 2).
In addition, 39 plants cultivated from seeds obtained from two other localities in Argentina (accessions 2106 and 2108 in Table 1 and Table 2) were inconclusively determined as $P$. brachiata ( $P$. officinarum $\times P$. piloselloides $/$ bauhini, hybrid formula $P$. officinarum $>P$. piloselloides/bauhini) or $P$. piloselliflora $(P$. officinarum $\times P$. floribunda, hybrid formula $P$. officinarum $\geq P$. floribunda). These plants were highly homogeneous in morphology within each of the two recovered accessions, with the exception of a single plant within accession 2108 , which later turned out to be of a deviating cytotype (see below). Although the overall morphological appearance was slightly different between accessions 2106 and 2108, the variation of all cultivated plants corresponded to the species $P$. brachiata/P. piloselliflora. These plants belonged to three aneuploid cytotypes: hyperpentaploid $(2 n=46$, accession 2106 in Table 2, Fig. 2B), hypopentaploid $(2 n=$ 44, accession 2108 in Table 2, Fig. 2C), and hypertetraploid (a sporadic cytotype with $2 n$ $=39$, accession 2108 in Table 2, Fig. 3A). The overall morphological appearance of the last aberrant individual $(2 n=39)$ still allowed to distinguish it from the other aneuploid $(2 n=$ 44) plants constituting accession 2108. Pollen stainability reached $80 \%$ and $88 \%$ in an euhexaploid $(2 n=54)$ plant of $P$. officinarum (accession 2115) and in the aneuploid $(2 n=46)$ plant of $P$. brachiata/P. piloselliflora (accession 2106), respectively. 
Bol. Soc. Argent. Bot. 56 (3) 2021

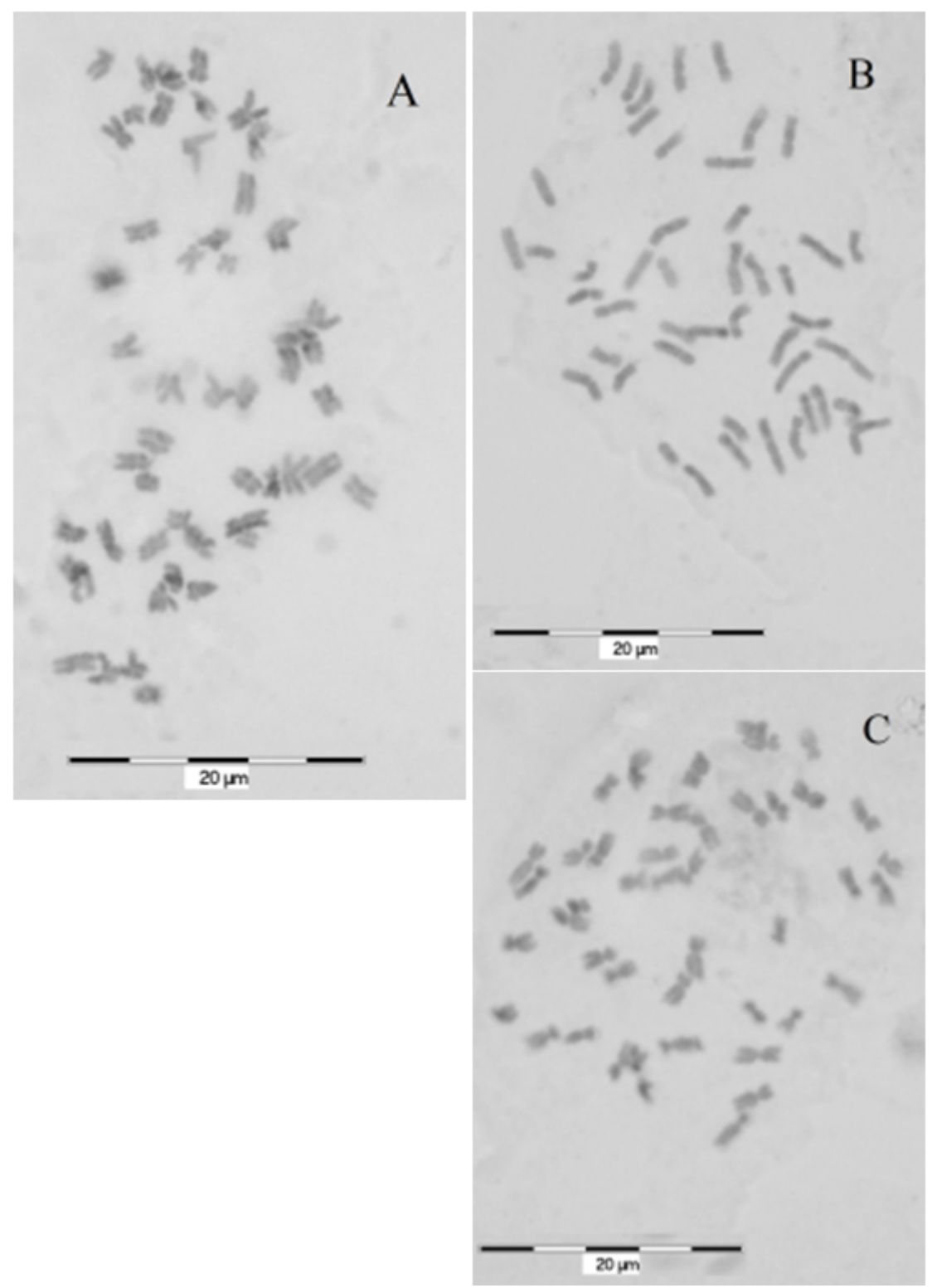

Fig. 2. Chromosomes in aneuploid cytotypes of Pilosella. Aneuploid plants were raised from seeds originating from altogether three populations in southern Patagonia (accession numbers follow Table 1 and Table 2). The mitotic metaphases were obtained from root-tip meristems. A: accession 2104, a putative hybrid of $P$. officinarum with another (unknown) species, $2 n=51$. B: accession 2106 , a hybridogeneous taxon of $P$. brachiata/P. piloselliflora, $2 n=46$. C: accession 2108 , a hybridogeneous taxon of $P$. brachiata/ $P$. piloselliflora, $2 n=44$.

\section{Clonal structure}

All obtained hexaploids assigned to $P$. officinarum shared an identical isozyme phenotype (labelled ' $a$ ' in Table 2). A simultaneous analysis of these plants with hexaploid P. officinarum from two localities in Chilean Patagonia that had been examined in a previous study (Krahulec \& Krahulcová, 2011) revealed a concordance in all analysed isozyme phenotypes, suggesting isoclonality. One hypo-hexaploid plant, 


\section{A. Krahulcová and F. Krahulec - Pilosella in Patagonia}
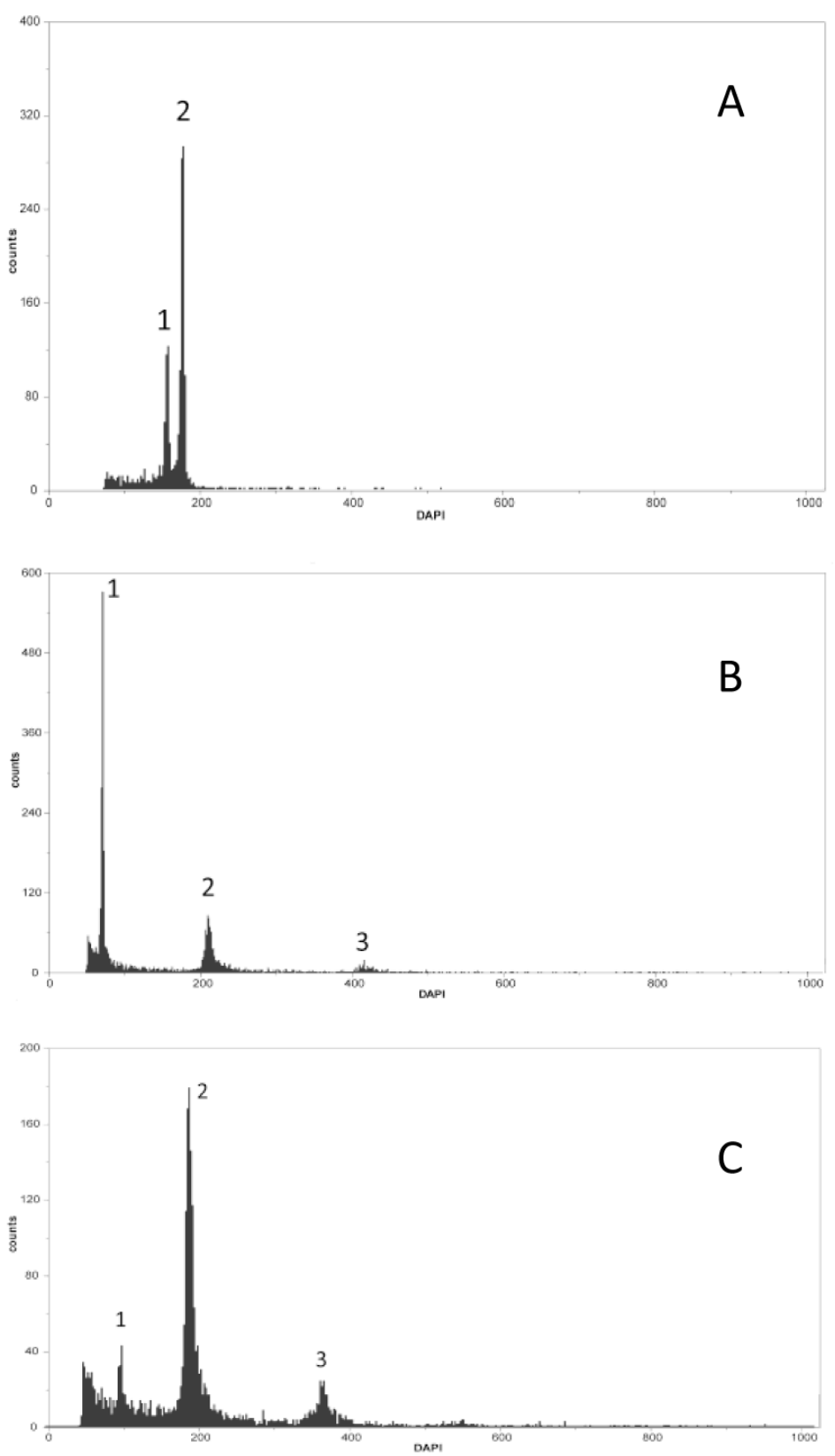

Fig. 3. Flow-cytometric fluorescence histograms. A: Pilosella brachiata/P. piloselliflora, accession 2108: simultaneous analysis of DAPI-stained nuclei of four hypo-pentaploid seedlings (peak 2 , chromosome number determined as $2 n=44$ ) and a single hyper-tetraploid seedling (peak 1 , chromosome number determined as $2 n=$ 39). B: P. officinarum, accession 2105: simultaneous FCSS analysis of two seeds sampled from plants in the field; diploid $P$. lactucella used as the internal standard (peak 1). The histogram represents the fluorescence intensity of DAPI-stained nuclei of apomictically derived hexaploid embryos (6x, peak 2$)$ and of dodecaploid autonomously formed endosperm (12x, minor peak 3). C: P. officinarum, accession 2104: FCSS analysis of a pooled sample of ten seeds sampled from plants in the field. The histogram represents the fluorescence intensity of DAPI-stained nuclei of a trihaploid embryo ( $3 x$, minor peak 1$)$, of other hexaploid embryos (6x, peak 2 ) and of dodecaploid endosperm (12x, minor peak 3 ) attributed to hexaploid embryos. The peak of hexaploid endosperm, which is attributed to a trihaploid embryo, is overlapped by peak 2 . All accession numbers follow Table 1 and Table 2 . 
corresponding in morphology to a hybrid of $P$. officinarum and an unknown parent $(2 n=51$, accession 2104 in Table 2), also exhibited isozyme phenotype 'a', which was assigned to typical hexaploid $P$. officinarum. Seven pentaploid plants of $P$. officinarum that constituted accession 2113 from Chile had a concordant isozyme phenotype (labelled ' $g$ ' in Table 2) with an analogous pentaploid $P$. officinarum that had previously been recorded at another locality in the country (Fig. 1, Krahulec \& Krahulcová, 2011). Six analysed plants that represented $P$. caespitosa and were sourced from two localities in Argentina (accessions 2102 and 2111) shared a common isozyme phenotype (labelled ' $b$ ' in Table 2).

Clonal diversity within an individual cytotype was only recorded in two accessions, 2106 and 2108, from populations in Argentina, assigned to $P$. brachiata/P. piloselliflora (Table 2). These were eighteen hyper-pentaploid plants $(2 n=46)$ analysed within accession 2106 , which possessed three isozyme phenotypes, as well as twenty analysed hypopentaploid plants $(2 n=44)$ within accession 2108 (Table 2). Comparison between accessions 2106 and 2108 found that plants from these accessions shared the most common isozyme phenotype ' $d$ ' and also the less common isozyme phenotype 'c' (Table 2). In general, all five isozyme phenotypes (labelled 'c', 'd', 'e', ' $\mathrm{f}$ ' and ' $\mathrm{h}$ ' in Table 2) that were detected in accessions 2106 and 2108 were similar to each other in their isozyme patterns, but certain differences were still recorded among them. Specifically, the isozyme phenotypes ' $c$ ', ' $d$ ', ' $\mathrm{e}$ ' and ' $\mathrm{h}$ ' had a rather distinct isozyme pattern of the enzyme EST (for a demonstration of isozyme phenotypes in selected plants, see Fig. 4) whereas the enzymes AAT, LAP and 6-PGDH/ PGM showed a uniform pattern. The isozyme phenotype 'f' was characterized by a distinct pattern of the enzyme 6-PGDH whereas the other three enzymes had a uniform pattern.

\section{Potential for parthenogenesis in plants grown from seeds}

A total of 21 raised plants selected to cover all recorded taxa were tested for parthenogenetic seed formation (Table 2). All these plants set a normal amount of seeds in emasculated capitula (not quantified), implying parthenogenetic and therefore highly probably apomictic reproduction. Emasculation experiments were not done in time in the case of aneuploid accession 2108, and plants produced normal seeds following open-pollination. The seed set was not evaluated in one aneuploid individual $(2 n=51)$ from accession 2104 (Table 2) because of damage to fruiting capitula caused by insects. Emasculation experiments were not carried out for accessions $2103,2113+2114,2115,2116$ and 2117, which were found to be isoclonal within the hexaploid cytotype of $P$. officinarum (see above) and shared isozyme phenotypes with two apomictic clones of $P$. officinarum previously identified in the region under study (Table 2).

\section{Reproductive origins of seeds from the field}

A total of 52 seeds from three localities were screened for seed origin. All the FCSS analyses of seed doublets revealed an apomictic $(2 n+$ 0 ) origin of these seeds (accessions 2104, 2105 and 2108 in the Table 3, Fig. 3B). The embryos ascribed to $P$. officinarum (accessions 2104 and 2105) were hexaploid. The ploidy of embryos in accession 2108 (assigned to P. brachiata/P. piloselliflora) corresponded to an approximately pentaploid ploidy level, which is in agreement with a hypopentaploid chromosome number of $2 n=44$ that was detected in parallelly cultivated plants (Table 3). FCSS analyses of pooled seed samples comprising ten seeds (100 seeds were analysed in total) revealed a prevalence of hexaploid embryos in seeds of $P$. officinarum. In addition, three embryos (i.e. $6 \%$ out of all analysed embryos attributed to $P$. officinarum) were triploid, indicating a polyhaploid origin (accession 2104 in the Table 4, Fig. 3C). All analysed embryos in pooled seed samples of $P$. brachiata/P. piloselliflora were approximately pentaploid (accession 2108 in the Table 4), as were the embryos in the seed doublets (see above). Analyses of pooled seed samples yielded a minor endosperm peak besides the major embryo peak in most histograms (Fig. 3C). This endosperm peak was always positioned at approximately double the distance of the major embryo peak, implying that an overwhelming majority of analysed embryos were of apomictic origin $(2 n$ $+0)$. Each of these embryos had the same ploidy level as the respective apomictic mother. 


\section{A. Krahulcová and F. Krahulec - Pilosella in Patagonia}

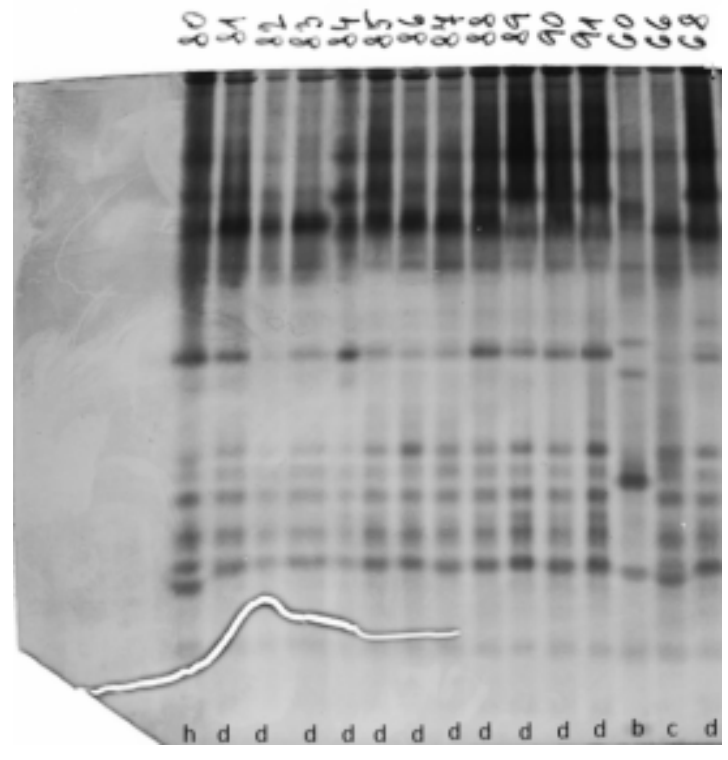

Fig. 4. Illustration of isozyme patterns in Pilosella acquired from analysis of enzyme system esterases (EST). The numbers at the top (codes of laboratory samples) correspond to individual cultivated plants; the letters at the bottom correspond to specific isozyme phenotypes as presented in Table 2 . The numbers 66, 68 and 80-91 represent cultivated accession 2106 (Pilosella brachiata/P. piloselliflora) whereas the number 60 represents cultivated accession 2111 (Pilosella caespitosa). Only some of the plants constituting accessions 2106 and 2111 (Table 2) are included here.

\section{Discussion}

\section{Taxonomic, clonal and cytotype diversity}

Here we report $P$. caespitosa as a new species for the flora of Argentina. With all probability it will be found also in the Chilean part of Patagonia in due time.

The history of the invasion of Pilosella officinarum in Patagonia is quite recent. Soon after it was recorded in Patagonia for the first time (Moore, 1983), this species was reported to invade the northern Tierra del Fuego rangelands (Livraghi et al., 1998). Later, two apomictic cytotypes/clones of $P$. officinarum were identified in southernmost Chile, the Magallanes province, namely a hexaploid clone occurring at two localities and a pentaploid clone occurring at another (Krahulec \& Krahulcová,
2011). The hexaploid clone of $P$. officinarum probably has a broader distribution in southern Patagonia because we recorded it at nine additional localities in the present study (Fig. 1, Table 1, Table 2). Furthermore, we identified both previously reported clones/cytotypes of $P$. officinarum in one mixed pentaploid/hexaploid population (accessions 2113 and 2114 in Table 2, Fig. 1), which constitutes the first record of a mixed-cytotype population of Pilosella in Patagonia. Each individual leaf rosette of $P$. officinarum forms a single inflorescence (capitulum; Bräutigam, 2017) and both cytotypes recorded in southern Patagonia produce clonal apomictic seeds (Krahulec \& Krahulcová, 2011). From the aforesaid mixed population, fruiting capitula were sampled separately and progeny originating from a single capitulum was always homogeneous as to its ploidy level; that is, it was either hexaploid or pentaploid (Table 2). Therefore, each of the either hexaploid or pentaploid capitula must correspond to an individual hexaploid/ pentaploid maternal rosette of $P$. officinarum in the source mixed-cytotype population and no intercytotype was recorded.

The pentaploid isoclonal apomictic plants raised from seeds originating from two localities in southern Argentina (accessions 2102 and 2111 in Table 1 and Table 2) were classified as Pilosella caespitosa, which is a new species for Patagonia. Similarly, the discovery of aneuploid apomictic and polyclonal plants classified as $P$. brachiata/P. piloselliflora implies the occurrence of another species of Pilosella in Argentinian Patagonia (accessions 2106 and 2108 in Table 1 and Table 2). Based on morphology, however, the plants in these two accessions were determined unequivocally as either $P$. brachiata or $P$. piloselliflora. These two hybridogeneous species of Pilosella share $P$. officinarum as one of the parents (Bräutigam \& Greuter, 2007-2009; Bräutigam, 2017). The common predominance of morphological characters of $P$. officinarum in the species $P$. brachiata and $P$. piloselliflora, respectively, can hinder their identification. Interestingly, both these accessions of $P$. brachiata/P. piloselliflora shared two most common isozyme phenotypes (labelled ' $c$ ' and ' $d$ ' in Table 2) that were specific to this taxon whereas the other three distinct isozyme phenotypes (labelled 'e', ' $\mathrm{f}$ ' and ' $\mathrm{h}$ ' in Table 2) were similar to each other. Such similarity in the pattern of isozyme phenotypes 
may imply a close genetic relation between two populations of $P$. brachiata/P. piloselliflora that are situated approximately $45 \mathrm{~km}$ apart (accessions 2106 and 2108 in Fig. 1). Nevertheless, each of these two separate populations represents a specific genotype(s), as implies the cytotype diversity of raised apomictic and aneuploid progeny (Table 2). Evidently, aneuploidy is compatible with viability in polyploid Pilosella biotypes, as has already been shown in mixed-cytotype populations in Europe (e.g. Krahulcová et al., 2009, 2014).

Summarizing all previously published data (see the Introduction for references) and those presented in this study, the alien flora of Patagonia currently includes seven Pilosella species, both basic ( $P$. aurantiaca, $P$. caespitosa, $P$. officinarum and $P$. piloselloides) and hybridogeneous ( $P$. flagellaris, $P$. floribunda and tentatively classified $P$. brachiata/P. piloselliflora). No mixed-species population was detected among those examined because each of the thirteen populations sampled were composed of a single taxon.

\section{Apomictic nature of populations and origins of variation}

The studied polyploid populations of Pilosella in southern Patagonia are apomictic, as can be inferred from (a) the formation of parthenogenetic seeds in raised progeny plants (Table 2), (b) the apomictic origins of analysed seeds that were produced in the field (Tables 3 and 4), and (c) the maintenance of maternal ploidy level in progeny embryos (Tables 3 and 4). The low frequency of trihaploid embryos recorded among hexaploid embryos of $P$. officinarum (Table 4) suggests a low degree of residual sexuality in this apomictic cytotype. This finding corresponds with the wellknown facultativeness of apomixis in Pilosella (e.g. Bicknell \& Koltunow, 2004; Fehrer et al., 2007). The apomictic character of $P$. officinarum and $P$. caespitosa in Patagonia is also reflected in the clonal homogeneity of the raised plants within individual species and cytotypes (Table 2). At least five different but probably closely related aneuploid genotypes were found in two apomictic accessions of $P$. brachiata/P. piloselliflora sampled from two separate populations (Table 2, Fig. 1). The minor genotype and cytotype diversity recorded between and within these two accessions may imply occasional sexual mating within the source populations. Both the eu-hexaploid $P$. officinarum $(2 n=54)$ and the hyper-pentaploid $P$. brachiata/P. piloselliflora $(2 n=46)$ exhibited fairly high pollen stainability implying a capacity for sexual mating as the pollen parent. This agrees with the fact that, despite autonomous apomixis independent of pollen, most polyploid apomictic biotypes of Pilosella produce sufficient amounts of viable reduced pollen allowing them to serve as the pollen parent (Rotreklová \& Krahulcová, 2016).

The unavailability of maternal plants from the field and the design of the seed sampling did not allow us to explain with certainty the origin of the aneuploids grown from the seeds. Each of the respective accessions 2104, 2106 and 2108 (Table 2) was composed of pooled progeny of an unknown number of maternal individuals (see the Material and methods). Because living plants were not collected, neither morphological nor karyological traits could be compared between any maternal plant from the field and the respective progeny array raised from the seeds sampled. Therefore, each of the aneuploid progeny individuals originated either de novo within an euploid population or as a copy of the maternal aneuploid genome inherited through apomixis. The single aneuploid individual in accession 2104 was most likely generated de novo within a hexaploid population of $P$. officinarum because it was raised among eu-hexaploid plants grown from seeds sampled from the same population (Table 2). Moreover, one morphological peculiarity distinguished this single aneuploid plant from the other raised eu-hexaploid plants of $P$. officinarum, suggesting occasional hybridization of $P$. officinarum with another (unknown) species. The putative hybridizing parents were most likely a hexaploid of $P$. officinarum and a pentaploid of an unknown species of Pilosella because the aneuploid hybrid progeny $(2 n=51)$ had a chromosome number between the pentaploid $(2 n=45)$ and the hexaploid $(2 n=54)$ ploidy level. However, potential heterogeneity among fruiting plants in the field allows for an alternative scenario. Specifically, the parent of the hybrid apomictic plant with an aneuploid the chromosome number of $2 n=51$ could theoretically be already established at the locality and its single aneuploid progeny individual could have happened to be raised from an apomictic seed.

Progeny accessions 2106 and 2108 most likely originated from two aneuploid apomictic 


\section{A. Krahulcová and F. Krahulec - Pilosella in Patagonia}

populations of $P$. brachiata/P. piloselliflora that were already established in the field. This assumption is based on (a) the reproduction mode and morphological appearance, (b) variation in chromosome numbers, and (c) clonal structure. Specifically, (a) the remaining seeds from which plants of accession 2108 were raised were of apomictic origin (Tables 3 and 4). Although no remaining source seeds of accession 2106 were available, the obtained progeny produced parthenogenetic seeds, implying inherited apomictic reproduction as well (Table 2). A great uniformity in overall morphological appearance was observed among the plants cultivated from seeds of both accessions, which also supports an apomictic origin of the seeds sampled in the field. (b) All cytotyped progeny cultivated from seeds in accessions 2106 and 2108 was exclusively aneuploid; the aneuploid chromosome numbers were clustered into three cytotypes differing by two chromosomes in most of the plants analysed (Table 2). (c) As inferred from isozyme phenotypes, the clonal structure of both these accessions indicated the sharing of two most common clones (genotypes), the other three clones being considerably rarer (Table 2). All five detected clones are probably closely related to each other, as implied by the similarity of their respective isozyme phenotypes.

It is probable that these two aneuploid populations of $P$. brachiata/P. piloselliflora arose recently in Argentinian Patagonia by occasional interspecific hybridization. Pilosella officinarum as well as $P$. piloselloides and $P$. floribunda occur as non-indigeneous taxa in Patagonia (Zuloaga \& Morrone, 1999; Krahulec \& Krahulcová, 2011), and the presence of these putative parental species is sufficient for the formation of both P. brachiata (DC.) F. W. Schultz \& Sch. Bip. (P. officinarum $\times P$. piloselloides $/ P$. bauhini $)$ and $P$. piloselliflora (Nägeli \& Peter) Soják $(P$. officinarum $\times P$. floribunda; Bräutigam, 2017). The shared putative parent Pilosella officinarum is apomictic in Patagonia, but the rarity of polyhaploid progeny (Table 4) suggests some degree of residual sexuality operating in the common hexaploid clone. Facultatively apomictic reproduction might also be expected in P. floribunda in Patagonia because this is the reproduction mode of most populations of this species in Europe (Krahulec et al., 2004, 2008). The third putative parental species, P. piloselloides, is both sexual and apomictic in Europe (Rotreklová et al., 2005). In spite of the expected apomictic reproduction, the putative parental biotypes might occasionally hybridize as either parent owing to residual sexuality operating in apomictic mothers and to the production of viable pollen (e.g. Fehrer et al., 2007; Rotreklová \& Krahulcová, 2016). The two apomictic populations of $P$. brachiata/P. piloselliflora in Patagonia exhibited slight diversity in their aneuploid chromosome numbers and also in their isozyme phenotypes (Table 2). Such variation could be derived from occasional sexual mating that potentially shaped the progeny of the primary interspecific hybrids. The diverse aneuploid cytotypes could then have arisen by irregular male/female meiosis during sporogenesis.

\section{Increasing risk of invasive hybrids in Patagonia}

The plants raised from seeds appear to be apomictic and species-uniform within populations in southern Patagonia examined to date. Residual sexuality and viable pollen are two crucial attributes allowing sexual mating of a facultative apomict as either parent. Both attributes needed for occasional hybridization were found in the hexaploid cytotype of $P$. officinarum, which is not rare in southern Patagonia. Indeed, the properties of plants obtained by the cultivation of seeds sampled in the field imply sporadic hybridization of $P$. officinarum with another species. However, the way seeds were sampled for this study does not allow us to ascertain whether the putatively hybrid plants had already been established in the field, or whether the hybrid seeds originated de novo. Regardless of this missing information, the following traits that may be indicative of ongoing hybridization in the field were observed in the seed-cultivated plants: clonal and cytotype diversity among progeny originating from certain populations, aneuploidy and a morphological affiliation of putative hybrids with $P$. officinarum, which was most likely one of their parents. One of the aneuploid hybrids that were tentatively classified as the hybridogeneous species $P$. brachiata/P. piloselliflora produced fairly viable pollen, similarly to that of eu-hexaploid $P$. officinarum. Consequently, both the biotypes, the putatively parental one ( $P$. officinarum) and the derived one ( $P$. brachiata/P. piloselliflora) can take part in sexual mating as the male parent. Furthermore, the existence of a mixed-cytotype 
population of $P$. officinarum, which was recorded in Patagonia for the first time, may increase the likelihood of inter-cytotype hybridization within this species.

Hybrids of many angiosperm taxa have become invasive in their secondary distribution areas regardless of whether a native species had hybridized with an introduced one, or whether both the parents had been introduced (Ellstrand \& Schierenbeck, 2000). In general, polyploidy and clonal growth are rather common among successful plant invaders, especially those capable of uniparental reproduction, including apomixis (e.g. Rambuda \& Johnson, 2004; te Beest et al., 2012). However, invasive or potentially invasive apomictic hybrids that themselves had originated from a facultatively apomictic parent or parents are not common. Such hybrids have been detected, for example, in the genera Amelanchier (Ellstrand \& Schierenbeck, 2000) and Rubus (Clark \& Jasieniuk, 2012) of the Rosaceae family. Another example are non-indigenous species of Pilosella (Asteraceae) hybridizing in New Zealand (Morgan-Richards et al., 2004; Trewick et al., 2004). Similarly, the present study recorded some signs of interspecific hybridization of non-native Pilosella in southern Patagonia. Because of polyploidy, clonal growth and facultative apomixis allowing occasional hybridization, non-indigenous biotypes of Pilosella pose a potential risk that invasive hybrids will arise in this part of the species' secondary distribution area.

\section{Conclusions}

The following species of Pilosella have so far been mentioned as alien in Patagonia: P. aurantiaca, P. flagellaris, P. floribunda, P. officinarum and $P$. piloselloides. The present study inquires into the diversity of progeny plants grown from seeds sampled at thirteen populations of Pilosella in southern Argentina and Chile. The plants were examined for their taxonomic identity, DNA ploidy level (using flow cytometry), chromosome number, formation of parthenogenetic seeds and clonal identity (using isozyme phenotypes). No mixedspecies population was recorded. Two apomictic clones of $P$. officinarum (one pentaploid and the other hexaploid), which had previously been reported from Chilean Patagonia, were found in additional populations, of which eight were hexaploid and one was mixed in its cytotype composition. A new species for Patagonia, the apomictic pentaploid $P$. caespitosa, was represented by isoclonal plants grown from seeds originating from two populations in Argentina. Some of the progeny plants cultivated from seeds sampled at three localities represented seed-fertile aneuploids the morphology of which implied a hybrid origin and indicated $P$. officinarum as one of the parents. Specifically, one aneuploid $(2 n=51)$ hybrid plant of $P$. officinarum and an undetermined species was found among other eu-hexaploid $(2 n=54)$ plants of $P$. officinarum constituting a progeny accession sourced from a population in Chile. Other accessions, originating from two populations in Argentina, were exclusively aneuploid. Their morphology resembled either $P$. brachiata $(P$. officinarum $>P$. piloselloides/bauhini) or $P$. piloselliflora ( $P$. officinarum $\geq P$. floribunda), which are two mutually related hybridogeneous species native in Europe. These two aneuploid accessions comprised a single hypertetraploid plant $(2 n=39)$ and seventeen plants that were polyclonal within each of two approximately pentaploid cytotypes $(2 n=44,2 n=46)$. The presence of seed-fertile, aneuploid and parthenogenetic hybrids among the cultivated plants signifies an increased risk of the formation of new hybridogeneous genotypes of Pilosella in southern Patagonia. If such new genotypes are formed, they may have greater evolutionary and invasive potential.

\section{Author Contributions}

AK did all experimental work and prepared first draft of the paper; FK participated on plant determination and prepared final version of the paper.

\section{Acknowledgements}

We thank Petra Šarhanová (University of Vienna, Austria) and Erwin Domínguez (INIA Kampenaike, Punta Arenas, Chile) who collected seeds in Patagonia, Ivana Plačková (Průhonice) for isozyme studies, Siegfried Bräutigam (Germany, 


\section{A. Krahulcová and F. Krahulec - Pilosella in Patagonia}

Dresden) for help with plant determination, Juan Manuel Gorospe for the translation of Summary into Spanish, and Fred Rooks (Průhonice) for language correction of the manuscript. Jan Wild is acknowledged for the preparation of the map. Two reviewers are acknowledged for their critical remarks and suggestions. This work was supported by the Czech Academy of Sciences (long-term research \& development project No. RVO 67985939).

\section{BibliogRAPHY}

ALEXANDER, M. P. 1969. Differential staining of aborted and nonaborted pollen. Stain Technol. 44: 117-122.

ARIZA ESPINAR, L. \& M. M. CERANA. 2015. Hieracium L. In: ZULOAGA, F. O., M. J. BELGRANO \& A. M. ANTÓN (eds.), Flora Argentina Vol. 7, Tomo II, pp. 15-42. Darwinion, CONICET, San Isidro.

BECKMANN, M., A. ERFMEIER \& H. BRUELHEIDE. 2009. A comparison of native and invasive populations of three clonal plant species in Germany and New Zealand. J. Biogeogr. 36: 865-878. https:// doi.org/10.1111/j.1365-2699.2008.02048.x

BECKMANN, M., H. BRUELHEIDE \& A. ERFMEIER. 2011. Germination responses of three grassland species differ between native and invasive origins. Ecol. Res. 26: 763-771. https://doi.org/10.1007/s11284-011-0834-3

BICKNELL, R. A. \& A. M. KOLTUNOW. 2004. Understanding apomixis: Recent advances and remaining conundrums. Plant Cell 16: S228-S245. https://doi.org/10.1105/tpc.017921

BRAUN, K., M. B. COLLANTES, L. YAHDJIAN, C. ESCARTIN \& J. A. ANCHORENA. 2019. Increased litter decomposition rates of exotic invasive species Hieracium pilosella (Asteraceae) in Southern Patagonia, Argentina. Plant Ecol. 220: 393-403. https://doi.org/10.1007/s11258-019-00922-3

BRÄUTIGAM，S. \& W. GREUTER. 2007-2009. Pilosella. In: GREUTER, W. \& E. E. VON RAAB-STRAUBE (eds.), Compositae. Euro+Med Plant Database - the information resource for Euro-Mediterranean plant diversity. Disponible en: http://ww2.bgbm.org/EuroPlusMed/PTaxonDetail. asp? NameCache $=$ Pilosella\&PTRefFk $=7000000$ [Acceso: 6 November 2017].
BRÄUTIGAM, S. 2017. Pilosella Vaill. In: Jäger, E. J. (ed.), Rothmaler Exkursionsflora von Deutschland, Gefäßpflanzen: Grundband, Ed. 21. pp. 817-829. Spektrum Akademische Verlag, Heidelberg, Berlin.

CHAPMAN, H.M., G. J. HOULISTON, B. ROBSON \&

I. ILINE. 2003. A case of reversal: the evolution and maintenance of sexuals from parthenogenetic clones in Hieracium pilosella. Int. J. Plant Sci. 164: 719728. https://doi.org/10.1086/376819

CIPRIOTTI, P. A., R. B. RAUBER, M. B. COLLANTES, K. BRAUN \& C. ESCARTÍN. 2010. Hieracium pilosella invasion in the Tierra del Fuego steppe, Southern Patagonia. Biol. Invasions 12: 2523-2535. https://doi.org/10.1007/s10530-009-9661-7

CIPRIOTTI, P. A., R. B. RAUBER, M. B. COLLANTES, K. BRAUN \& C. ESCARTÍN. 2012. Control measures for a recent invasion of Hieracium pilosella in Southern Patagonian rangelands. Weed Res. 52: 98-105. https://doi.org/10.1111/j.1365-3180.2011.00897.x

CIPRIOTTI, P.A., M. B. COLLANTES, C. ESCARTÍN, S. CABEZA, R. B. RAUBER, \& K. BRAUN. 2014. Experiencias de largo plazo para el manejo de pastizales: El caso de Hieracium pilosella en la Estepa Fueguina. [Long-term experiences for the management of a grassland invasive herb: The case of Hieracium pilosella L. in the Fuegian Steppe.] Ecologia Austral 24: 135-144.

CLARK, L.V. \& M. JASIENIUK. 2012. Spontaneous hybrids between native and exotic Rubus in the Western United States produce offspring both by apomixis and by sexual recombination. Heredity 109: 320-328. https://doi.org/10.1038/hdy.2012.45

COOK, M. M, A. MARTELLI, M. SLELMAN \& P. A. CIPRIOTTI. 2021. The role of competition invader colonization along stress gradients in the Fuegian steppe. Oecologia 195: 1031-1040. https://doi.org/10.1007/s00442-021-04894-y

DAY, N. J. \& H. L. BUCKLEY. 2011. Invasion patterns across multiple scales by Hieracium species over 25 years in tussock grasslands of New Zealand's South Island. Austral. Ecol. 36: 559-570. https://doi.org/10.1111/j.1442-9993.2010.02191.x

DOLEŽEL, J. \& W. GÖHDE. 1995. Sex determination in dioecious plant Melandrium album and M. rubrum using high resolution flow cytometry. Cytometry 19: 103-106.

DYER, A. F. 1963. The use of lacto-propionic orcein in rapid squash methods for chromosome preparations. Stain Technol. 38: 85-90. 
ELLSTRAND, N. C. \& K. A. SCHIERENBECK. 2000. Hybridization as a stimulus for the evolution of invasiveness in plants? Proc. Nat. Acad. Sci. 97: 7043-7050. https://doi.org/10.1073/pnas.97.13.7043

FEHRER, J., A. KRAHULCOVÁ., F. KRAHULEC, J. CHRTEK JR., R. ROSENBAUMOVÁ \& S. BRÄUTIGAM. 2007. Evolutionary aspects in Hieracium subgenus Pilosella. In: Grossniklaus, U., E. Hörandl, T. Sharbel \& P. van Dijk. (eds.), Apomixis: Evolution, Mechanisms and Perspectives. Regnum Vegetabile 147, pp. 359-390. A.R.G. Gantner Verlag, Rugel.

GADELLA, T. W. J. 1984. Cytology and the mode of reproduction of some taxa of Hieracium subgenus Pilosella. Proc. Kon. Ned. Acad. Wetensch. C87: 387-399.

HAND, M. L., P. VÍT, A. KRAHULCOVÁ, S. D. JOHNSON, K. OELKERS, H. SIDDONS, J. CHRTEK JR., J. FEHRER \& A. M. G. KOLTUNOW. 2015. Evolution of apomixis loci in Pilosella and Hieracium (Asteraceae) inferred from the conservation of apomixis-linked markers in natural and experimental populations. Heredity 114: 17-26. https://doi.org/10.1038/hdy.2014.61

HARLAN, J. R. \& J. M. DE WET, 1975. On Ö. Winge and a prayer: the origins of polyploidy. Bot. Rev. 41: 361-390.

JENKINS, T. A., \& K. JONG.1996. Significance of polyploid variation in New Zealand Pilosella and Hieracium (Asteraceae). Bot. J. Scotl. 49: 75-87.

KRAHULCOVÁ, A. \& F. KRAHULEC. 2020. Ploidy level and breeding system in some populations of Pilosella (Asteraceae) in eastern and southern Slovakia. Thaiszia - J. Bot. 30: 37-58. https://doi.org/10.33542/TJB2020-1-04

KRAHULCOVÁ, A., F. KRAHULEC \& H. M. CHAPMAN. 2000. Variation in Hieracium subgen. Pilosella (Asteraceae): what do we know about its sources? Folia Geobot. 35: 319-338. https://doi.org/10.1007/BF02803122

KRAHULCOVÁ, A., F. KRAHULEC \& R. ROSENBAUMOVÁ. 2011. Expressivity of apomixis in $2 n+n$ hybrids from an apomictic and a sexual parent: Insights into variation detected in Pilosella (Asteraceae: Lactuceae). Sex. Plant Reprod. 24: 63-74. https://doi.org/10.1007/s00497-010-0152-x

KRAHULCOVÁ, A., S. PAPOUŠKOVÁ \& F. KRAHULEC. 2004. Reproduction mode in the allopolyploid facultatively apomictic hawkweed Hieracium rubrum (Asteraceae, $H$. subgen. Pilosella). Hereditas (Lund) 141: 19-30. https://doi.org/10.1111/j.1601-5223.2004.01845.x
KRAHUlCOVÁ, A., O. ROTREKLOVÁ, F. KRAHULEC, R. ROSENBAUMOVÁ \& I. PLAČKOVÁ. 2009. Enriching ploidy level diversity: the role of apomictic and sexual biotypes of Hieracium subgen. Pilosella (Asteraceae) that coexist in polyploid populations. Folia Geobot. 44: 281-306. https://doi.org/10.1007/s12224-009-9041-1

KRAHULCOVÁ, A., O. ROTREKLOVÁ \& F. KRAHULEC. 2014. The detection, rate and manifestation of residual sexuality in apomictic populations in Pilosella (Asteraceae, Lactuceae). Folia Geobot. 49: 239-258. https://doi.org/10.1007/s12224-013-9166-0

KRAHULCOVÁ, A. \& J. SUDA. 2006. A modified method of flow cytometric seed screen simplifies the quantification of progeny classes with different ploidy levels. Biol. Plant. 50: 457-460. https://doi.org/10.1007/s10535-006-0070-9

KRAHULEC, F. \& A. KRAHULCOVÁ. 2011. Ploidy levels and reproductive behaviour in invasive Hieracium pilosella in Patagonia. NeoBiota 11: 2531. https://doi.org/10.3897/neobiota.11.1349

KRAHULEC, F. \& A. KRAHULCOVÁ. 2018. Impact of interspecific hybridization within a polyploid agamic complex of Pilosella (Asteraceae, Lactuceae) in Bulgaria compared with Central Europe. Willdenovia 48: 345-362. https://doi.org/10.3372/wi.48.48302

KRAHULEC, F., A. KRAHULCOVÁ, J. FEHRER, S. BRÄUTIGAM, I. PLAČKOVÁ \& J. CHRTEK JR. 2004. The Sudetic group of Hieracium subgen. Pilosella from the Krkonoše Mts: a synthetic view. Preslia 76: 223-243.

KRAHULEC, F., A. KRAHULCOVÁ, J. FEHRER, S. BRÄUTIGAM \& F. SCHUHWERK. 2008. The structure of the agamic complex of Hieracium subgen. Pilosella in the Šumava Mts and its comparison with other regions in Central Europe. Preslia 80: 1-26.

LEONG-ŠKORNIČKOVÁ, J., O. ŠÍDA, V. JAROLÍMOVÁ, M. SABU, T. FÉR, P. TRÁVNÍČEK \& J. SUDA. 2007. Chromosome numbers and genome size variation in Indian species of Curcuma (Zingiberaceae). Ann. Bot. (Oxford) 100: 505-526. https://doi.org/10.1093/aob/mcm144

LIVRAGHI, E., S. CABEZA, R. KOFALT, G. HUMANO, M. MASCÓ \& L. MONTES. 1998. Documento de trabajo sobre Hieracium pilosella $\mathrm{L}$. Informe Téchnico INTA. [not seen cit. sec. Cipriotti et al. 2010]. 


\section{A. Krahulcová and F. Krahulec - Pilosella in Patagonia}

LOOMIS, E. S. \& L. FISHMAN. 2009. A continent-wide clone: population genetic variation of the invasive plant Hieracium aurantiacum (orange hawkweed; Asteraceae) in North America. Int. J. Plant Sci. 170: 759-765. https://doi.org/10.1086/599241

MAKEPEACE, W. 1985. Growth, reproduction, and production biology of mouse-ear and king devil hawkweed in eastern South Island, New Zealand. New Zealand J. Bot. 23: 65-78.

MATZK, F., A. MEISTER \& I. SCHUBERT. 2000. An efficient screen for reproductive pathways using mature seeds of monocots and dicots. Plant J. 21: 97-108. https://doi.org/10.1046/j.1365-313x.2000.00647.x

MOORE, D. M. 1983. Flora of Tierra del Fuego. Anthony Nelson, Shropshire, Missouri Botanical Garden, St. Louis.

MORGAN-RICHARDS, M., S. A. TREWICK, H. M. CHAPMAN \& A. KRAHULCOVÁ. 2004. Interspecific hybridization among Hieracium species in New Zealand: evidence from flow cytometry. Heredity 93: 34-42. https://doi.org/10.1038/sj.hdy.6800476

NÄGELI, C. \& A. PETER. 1885. Die Hieracien MittelEuropas, Piloselloiden. R. Oldenbourg, München.

OTTO, F. 1990. DAPI staining of fixed cells for highresolution flow cytometry of nuclear DNA. In: CRISSMAN, H.A. \& Z. DARZYNKIEWICZ (eds.), Methods in cell biology 33. pp. 105-110. Academic Press, San Diego.

PETER, A., 1884. Ueber spontane und künstliche Gartenbastarde der Gattung Hieracium sect. Piloselloidea. Bot. Jahrb. 5: 203-286, 418-496; 6: 111-136.

RAMBUDA, T. D. \& S. D. JOHNSON. 2004. Breeding systems of invasive alien plants in South Africa: does Baker's rule apply? Diversity and Distributions 10: 409-416. https://doi.org/10.1111/j.1366-9516.2004.00100.x

RAUBER, R. B., M. B. COLLANTES, P. A. CIPRIOTTI \& J. ANCHORENA. 2013. Biotic and abiotic constraints to a plant invasion in vegetation communities of Tierra del Fuego. Austral Ecology 38: 436-442. https://doi.org/10.1111/j.1442-9993.2012.02427.x

RAUBER, R. B., P. A. CIPRIOTTI \& M. B. COLLANTES. 2014. Local and intermediated intensity soil disturbances increase the colonization and expansion dynamics of an invasive plant in Southern Patagonian rangelands. Commun. Ecol. 15:
87-93. https://doi.org/10.1556/COMEC.15.2014.1.9 RODRIGUEZ, R., C. MARTICORENA, D. ALARCÓN, C. BAEZA, L. CAVIERES, V. L. FINOT, N. FUENTES, A. KIESSLING, M. MIHOC, A. PAUCHARD, E. RUIZ, P. SANCHEZ \& A. MARTICORENA. 2018. Catálogo de las plantas vasculares de Chile. Gayana Bot. 75: 1-430.

ROTREKLOVÁ, O. \& A. KRAHULCOVÁ. 2016. Estimating paternal efficiency in an agamic polyploid complex: pollen stainability and variation in pollen size related to reproduction mode, ploidy level and hybridogeneous origin in Pilosella (Asteraceae). Folia Geobot. 51: 175-186. https://doi.org/10.1007/s12224-016-9240-5

ROTREKLOVÁ, O., A. KRAHULCOVÁ, P. MRÁZ, V. MRÁZOVÁ, L. MÁRTONFIOVÁ, T. PECKERT \& B. ŠINGLIAROVÁ. 2005. Chromosome numbers and breeding systems of some European species of Hieracium subgen. Pilosella. Preslia 77: 177-195.

SCOTT, D. 1993. Response of Hieracium in 2 long-term manipulative trials. New Zealand J. Ecol. 17: 41-46.

SUDA, J., A. KRAHULCOVÁ, P. TRÁVNÍČEK \& F. KRAHULEC. 2006. Ploidy level vs. DNA ploidy level: an appeal for consistent terminology. Taxon 55: 447-450.

SUDA, J., A. KRAHULCOVÁ, P. TRÁVNÍČEK, R. ROSENBAUMOVÁ, T. PECKERT \& F. KRAHULEC. 2007. Genome size variation and species relationships in Hieracium sub-genus Pilosella (Asteraceae) as inferred by flow cytometry. Ann. Bot. (Oxford) 100: 1323-1335. https://doi.org/10.1093/aob/mcm218

TE BEEST, M., J. J. LE ROUX, D. M. RICHARDSON, A. K. BRYSTING K., J. SUDA, M. KUBEŠOVÁ \& P. PYŠEK. 2012. The more are better? The role of polyploidy in facilitating plant invasions. Ann. Bot. (Oxford) 109: 19-45. https://doi.org/10.1093/aob/mcr277

TREWICK, S. A., M. MORGAN-RICHARDS \& H. M. CHAPMAN. 2004. Chloroplast DNA diversity of Hieracium pilosella (Asteraceae) introduced to New Zealand: reticulation, hybridization and invasion. Amer. J. Bot. 91: 73-85. https://doi.org/10.3732/ajb.91.1.73

UGARTE, E., F. LIRA, N. FUENTES \& S. KLOTZ. 2011. Vascular alien flora, Chile. Check List 7: 365-382.

VALLEJOS, C. E. 1983. Enzyme activity staining. In: TANKSLEY, S. D. \& ORTON, T. J. (eds.), Isozymes in plant genetics and breeding, Part A. pp. 469-516. Elsevier, Amsterdam etc. 
Bol. Soc. Argent. Bot. 56 (3) 2021

WENDEL, J. F. \& WEEDEN, N. F. 1989. Visualisation and interpretation of plant isozymes. In: SOLTIS, D. E. \& SOLTIS, P. S. (eds.), Isozymes in plant biology. pp. 5-45. Dioscorides Press, Portland.

WILSON, L. M., J. FEHRER, S. BRÄUTIGAM \& G. GROSSKOPF. 2006. A new invasive hawkweed, Hieracium glomeratum (Lactuceae, Asteraceae), in the Pacific Northwest. Canad. J. Bot. 84: 133-
142. https://doi.org/10.1139/B05-149

ZAHN, K. H. 1922-1930. Hieracium. In: Ascherson, P. \& P. Graebner (eds.), Synopsis der mitteleuropäischen Flora 12: 1-492. Gebrüder Bornträger, Leipzig.

ZUlOAGA, F. O. \& O. MORRONE. 1999. Catálogo de las Plantas de la Argentina II, Dicotyledonae. Monogr. Syst. Bot. Missouri Bot. Gard. 74: 1-1269. 